\title{
Furosemide-induced Alterations in the Electrolyte Status, the Function of Renin-Angiotensin- Aldosterone System, and the Urinary Excretion of Prostaglandins in Newborn Infants
}

\author{
E. SULYOK, (43) F. VARGA, M. NÉMETH, I. TÉNYI, I. F. CSABA, T. ERTL, AND E. GYÖRY \\ Department of Obstetrics and Gynaecology and the First Department of Medicine, University of Pécs, Pécs, Hungary'
}

\section{Summary}

To assess the responsiveness of the renin-angiotensin-aldosterone system of the neonate to acute furosemide stimulation and the role of renal prostaglandins in mediating the response of the renin-angiotensin-aldosterone system, this study was carried out to determine simultaneously plasma renin activity, plasma aldosterone concentration, urinary aldosterone, prostaglandin $\mathbf{E}$, and prostaglandin $F_{2 \alpha}$ excretion along with determination of plasma electrolyte concentration and urinary electrolyte excretion.

Measurements were made on 19 newborn infants with mean birth weight and gestational age of $3009 \mathrm{~g}$ (range, 2700 to $4150 \mathrm{~g}$ ) and 38.7 wk (range, 36 to 41 wk) at the age of 4 to 7 days before and after IM administration of furosemide in a dose of $1 \mathrm{mg} / \mathrm{kg}$.

It was demonstrated that in response to furosemide, urine volume $(P<0.001)$, urinary sodium $(P<0.001)$, potassium $(P<$ $0.05)$, and chloride $(P<0.001)$ excretion increased significantly.

Furosemide administration also resulted in a significant increase from $4.41 \pm 2.00$ to $9.70 \pm 2.32 \mathrm{ng} / \mathrm{ml} / \mathrm{hr}(P<0.02)$ in plasma renin activity, from $1.17 \pm 0.22$ to $1.68 \pm 0.36 \mathrm{ng} / \mathrm{ml}(P<0.025)$ in plasma aldosterone, from $0.93 \pm 0.16$ to $1.53 \pm 0.35 \mu \mathrm{g} / 12 \mathrm{hr}$ $(P<0.025)$ in urinary aldosterone, from $17.53 \pm 3.37$ to $23.73 \pm$ $3.16 \mathrm{ng} / 12 \mathrm{hr}(P<0.025)$ in prostaglandin $E$, and from $16.48 \pm$ 4.12 to $26.27 \pm 4.12 \mathrm{ng} / 12 \mathrm{hr}(P<0.05)$ in prostaglandin $F_{2 a}$.

It is concluded that the renin-angiotensin-aldosterone system of the neonate responds to acute furosemide challenge in spite of its high baseline activity, and its response may be mediated by increased renal prostaglandin production.

\section{Speculation}

The demonstration of high basal activity of the renin-angiotensin-aldosterone system in "nonstimulated" healthy newborn infants prompted us to study whether this high baseline activity is or is not a rate-limiting determinant of the responsiveness of the renin-angiotensin-aldosterone system to furosemide stimulation. It is also to be clarified whether the increase in the activity of the renin-angiotensin-aldosterone system, if any, in response to furosemide administration could be ascribed to its direct effect on renal sodium transport and renal hemodynamics or whether it might be mediated by the furosemide-induced alterations in renal prostaglandin production.

In a series of recent publications, it has been reported that the activity of renin-angiotensin-aldosterone system (RAAS) is greatly elevated in the neonatal period $(3,5,6,8,14,18,20,22,24,26$, 31 ).

The pathogenesis of the increased activity is a matter of considerable interest and dispute. However, there is widespread agreement that several factors such as perinatal stress imposed by labor and delivery $(6,8,14,21,22)$, the low systemic blood pressure (5), the low renal blood flow (34), and the renal tubular unresponsiveness to aldosterone during the neonatal period $(15,33)$ might play an important role in producing hyperactivity of RAAS in the neonate.

Furthermore, our most recent studies provided suggestive evidences that the increased endogenous prostaglandin (PG) production during labor and delivery (36), and the increased urinary sodium loss in premature infants $(35,37)$ may also be implicated in the etiology of the neonatal hyperfunction of RAAS.

With respect to the well-established relationship between renal PG production and the RAAS $(12,13,29)$ as well as the relationship between renal PG's and urinary sodium excretion (10), it was of particular interest to study simultaneously the function of RAAS and the renal PG and sodium excretion in newborn infants subjected to furosemide challenge.

In an attempt to obtain information about the responsiveness of RAAS during the neonatal period and about the possible role of PG's in mediating its response to furosemide administration, the present study was designed to determine plasma renin activity (PRA), plasma aldosterone concentration (PA), urinary aldosterone excretion (UAE), and urinary prostaglandin $E$ (PGE) and prostaglandin $F_{2}\left(P F_{2 a}\right)$ excretion in relation to electrolyte balance in full-term newborn infants before and after furosemide administration.

\section{MATERIALS AND METHODS}

The study was carried out on 19 appropriate for date newborn infants with mean birth weights of $3009 \mathrm{~g}$ (range, 2700 to $4150 \mathrm{~g}$ ) and mean gestational age of $38.7 \mathrm{wk}$ (range, 30 to $41 \mathrm{wk}$ ). Male infants were selected for the study to overcome the technical difficulties in accurate urine collection. The mean study age was 5.2 days (range, 4 to 7 days). All infants presented moderate edema which was not related to striking pathologic condition. They had no history of severe birth asphyxia or clinical and laboratory evidences of renal disease, cardiac disease, and perinatal infection. All infants were breast fed; the daily fluid intake amounted to 90 to $100 \mathrm{ml} / \mathrm{kg} /$ day.

PRA, PA, plasma sodium, and potassium concentrations as well as UAE, urinary PGE, $\mathrm{PGF}_{2 a}$, sodium, and potassium excretion were determined before and after furosemide administration given in a dose of $1 \mathrm{mg} / \mathrm{kg}$ body weight.

Urine was fractionally collected for a period of $12 \mathrm{hr}$. The specimens were refrigerated, pooled, and stored at $-20^{\circ} \mathrm{C}$ until analysis. The collection started at 9 PM for a control period of 12 hr. At 9 AM, furosemide was administered IM, and urine collection continued for another $12 \mathrm{hr}$. Blood samples of 2 to $2.5 \mathrm{ml}$ were obtained at the end of the control period and about $3 \mathrm{hr}$ after furosemide administration.

PRA was measured radioimmunologically according to the method of Haber et al. (17) using SORIN-CEA-IRE RENK kits. $\mathrm{PA}$ and UAE measurement was made by radioimmunoassay (42) 
using ALDOK radioimmunoassay kits manufactured by SORINCEA-IRE. The sensitivity of the method, the normal values in our laboratory, and the interassay variations for PRA, PA, and UAE have been given in our previous paper (35).

Immunoreactive $\mathrm{PGE}$ and $\mathrm{PGF}_{2 \alpha}$ were measured by radioimmunoassay using Clinical Assays, Inc. radioimmunoassay kits. Each sample was assayed in duplicate, and the means were calculated.

The extraction and assay procedure followed the method of Jaffe et al. (19) and Gutierrez-Cernosek et al. (16) with some modifications. Ten $\mathrm{ml}$ of urine were used for analysis. Neutral lipids were removed with petroleum:ether, and PG's were extracted with ethyl acetate:isopropanol:0.2 $\mathrm{N} \mathrm{HCl} \mathrm{(3:3:1)} \mathrm{solution.}$ PG's were separated into fractions using silicic acid column chromatography, and the fractions were eluted with the mixture of benzene:ethyl acetate:methanol. For determination of PGE, the extract was converted to prostaglandin B by treatment with $1 \mathrm{~N}$ sodium hydroxide and radioimmunoassayed with $\mathrm{POB}_{1}$ antibody. The assay measured both $\mathrm{PGE}_{1}$ and prostaglandin $\mathrm{E}_{2}$ because both were converted to prostaglandin $B_{1}$ and prostaglandin $B_{2}$, respectively, by the alkaline treatment and prostaglandin $B_{2}$ crossreacted with the anti-BGB ${ }_{1}$.

The overall recovery rate of added PGE and $\mathrm{PGF}_{2 \alpha}$ was 47 and $52 \%$, respectively. The estimated values were corrected for these losses. The inter- and intraassay variation was 17 and $9 \%$ for $\mathrm{PGF}_{2 \alpha}$ and 21 and $11 \%$ for PGE, respectively. The sensitivity of the method for $\mathrm{PGF}_{2 a}$ and $\mathrm{PGE}$ was $10 \mathrm{pg} / \mathrm{ml}$.

Plasma and urinary sodium and potassium were measured by flame photometry. test.

Statistical analysis was performed by calculating Student's $t$

The purpose of the study was explained to each mother, and informed consent was obtained for blood sampling and urine collection.

\section{RESULTS}

The changes in plasma electrolyte concentration, urine volume, and urinary electrolyte excretion following furosemide administration are demonstrated in Table 1 . No change can be seen in plasma sodium concentration after the administration of furosemide. Plasma potassium concentration, however, tended to increase from the value of $5.62 \pm 0.40 \mathrm{mEq} /$ liter mean \pm S.E. during the control period to $6.04 \pm 0.44 \mathrm{mEq} /$ liter following furosemide treatment $(P>0.05)$.

Urine volume increased significantly from $17.84 \pm 1.74$ to 34.29 $\pm 2.67 \mathrm{ml} / \mathrm{kg} / 12 \mathrm{hr}$ after furosemide $(P<0.001)$. Furosemide administration also resulted in a significant rise in urinary sodium, potassium, and chloride excretion from the control values of 0.22 $\pm 0.03,0.11 \pm 0.02$, and $0.42 \pm 0.07 \mathrm{mEq} / \mathrm{kg} / 12 \mathrm{hr}$ to $2.62 \pm 0.30$ $(P<0.01), 0.20 \pm 0.03(P<0.05)$, and $2.89 \pm 0.34 \mathrm{mEq} / \mathrm{kg} / 12 \mathrm{hr}$ $(P<0.001)$, respectively.

The furosemide-induced alterations in PRA, PA, and UAE are shown in Figure 1. It appears in this figure that in response to furosemide administration PRA, PA, and UAE increased significantly from the control values of $4.41 \pm 2.00 \mathrm{ng} / \mathrm{ml} / \mathrm{hr}$ (PRA), $1.17 \pm 0.22 \mathrm{ng} / \mathrm{ml}(\mathrm{PA})$, and $0.93 \pm 0.16 \mu \mathrm{g} / 12 \mathrm{hr}$ to the levels of $9.70 \pm 2.32 \mathrm{ng} / \mathrm{ml} / \mathrm{hr}(P<0.02), 1.68 \pm 0.36 \mathrm{ng} / \mathrm{ml}(P<0.025$ on paired $t$ testing $)$, and $1.53 \pm 0.35 \mu \mathrm{g} / 12 \mathrm{hr}(P<0.025$ on paired $t$ test), respectively.

The changes in urinary excretions of PGE and PGF $_{2 a}$ following the furosemide injection are illustrated in Figure 2. The mean excretion rate of PGE was $17.53 \pm 3.37 \mathrm{ng} / 12 \mathrm{hr}$ in the control period, and due to the administration of furosemide, it increased significantly to the value of $23.73 \pm 3.16 \mathrm{ng} / 12 \mathrm{hr}(P<0.025$ on paired $t$ test).

The urinary excretion rate of $\mathrm{PGF}_{2 x}$ was $16.48 \pm 4.12 \mathrm{ng} / 12 \mathrm{hr}$ in the control period, and the furosemide administration resulted in a significant increase to attain a value of $26.27 \pm 42.12 \mathrm{ng} / 12$ hr $(P<0.05$ on paired $t$ test $)$

\section{DISCUSSION}

To assess the reactivity on RAAS following acute challenge, we applied furosemide administration in a single dose of $1 \mathrm{mg} / \mathrm{kg}$ body weight. Our experimental design, however, does not allow us to describe the time course of furosemide-induced alterations in the function of RAAS because hormones and electrolytes in plasma and urine were not measured serially. Instead, blood samples were obtained only once, $3 \mathrm{hr}$ after furosemide administration because its peak pharmacologic action is sustained for several $\mathrm{hr}(2,28)$. Similarly, urinary electrolyte and hormone excretion was not determined sequentially, but with regard to the approximately $6 \mathrm{hr}$ duration of furosemide action (28) and errors resulting from short-term urine collections, urine was collected for a period of $12 \mathrm{hr}$ for determinations.

Keeping in mind all these limitations, our findings should be

Table 1. Changes in plasma electrolyte concentration, urine volume, and urinary electrolyte excretion in newborn infants following furosemide treatment

\begin{tabular}{|c|c|c|c|c|c|c|}
\hline & \multicolumn{3}{|c|}{ Plasma } & \multicolumn{3}{|c|}{ Urine } \\
\hline & $\begin{array}{c}\text { Sodium } \\
\text { (mEq/liter) }\end{array}$ & $\begin{array}{c}\text { Potassium } \\
(\mathrm{mEq} / \text { liter })\end{array}$ & $\begin{array}{c}\begin{array}{c}\text { Volume } \\
(\mathrm{ml} / \mathrm{kg} / 12 \mathrm{hr})\end{array} \\
\end{array}$ & $\begin{array}{c}\text { Sodium } \\
(\mathrm{mEq} / \mathrm{kg} / 12 \mathrm{hr}) \\
\end{array}$ & $\begin{array}{c}\text { Potassium } \\
(\mathrm{mEq} / \mathrm{kg} / 12 \mathrm{hr})\end{array}$ & $\begin{array}{c}\text { Chloride } \\
(\mathrm{mEq} / \mathrm{kg} / 12 \mathrm{hr})\end{array}$ \\
\hline Before furosemide & $\begin{array}{l}142 \pm 1.65^{1} \\
\quad(18)\end{array}$ & $\begin{array}{l}5.62 \pm 0.40 \\
\quad(18)\end{array}$ & $\begin{array}{l}17.84^{2} \pm 1.74 \\
(19)\end{array}$ & $\begin{array}{l}0.22^{2} \pm 0.03 \\
\quad(19)\end{array}$ & $\begin{array}{l}0.11^{3} \pm 0.02 \\
\quad(18)\end{array}$ & $\begin{array}{l}0.42^{2} \pm 0.07 \\
(18)\end{array}$ \\
\hline After furosemide & $\begin{array}{c}141 \pm 0.93 \\
(18) \\
\end{array}$ & $\begin{array}{l}6.04 \pm 0.44 \\
(15) \\
\end{array}$ & $\begin{array}{l}34.29^{2} \pm 2.67 \\
(19)\end{array}$ & $\begin{array}{l}2.62^{2} \pm 0.30 \\
(19)\end{array}$ & $\begin{array}{l}0.20^{3} \pm 0.03 \\
(19)\end{array}$ & $\begin{array}{l}2.89^{2} \pm 0.34 \\
(17)\end{array}$ \\
\hline
\end{tabular}

\footnotetext{
${ }^{1}$ Mean \pm S.E.

${ }^{2} P<0.001$

${ }^{3} P<0.05$.
}

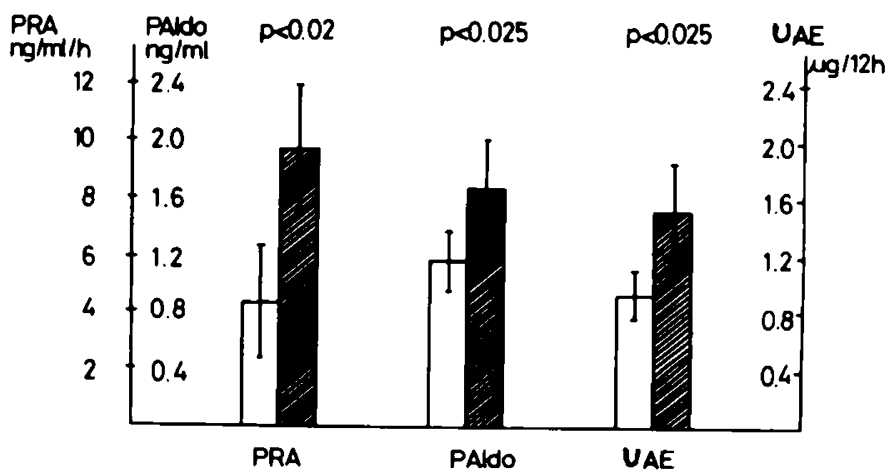

Fig. 1. PRA, PA, and UAE in newborn infants before and after furosemide administration. Bars, S.E. 
$\left.\begin{array}{l}\square \text { before } \\ \text { after }\end{array}\right\}$ furosemide administration

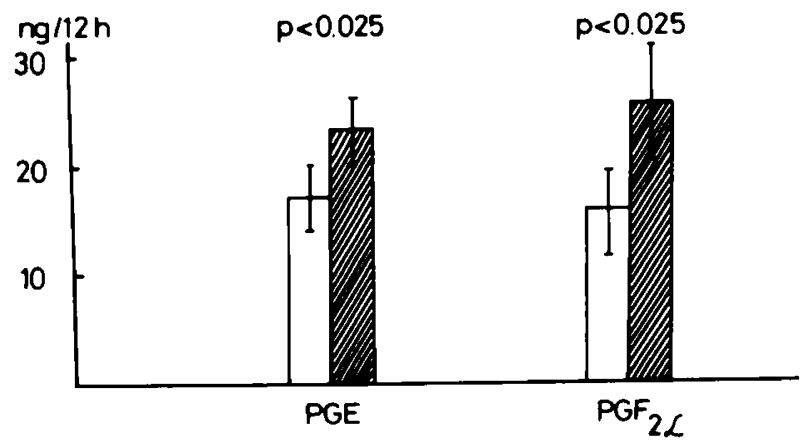

Fig. 2. Urinary excretion of $P G E$ and $P G F_{2 a}$ in newborn infants before and after furosemide administration. Bars, S.E.

considered as demonstrating the overall responsiveness of RAAS to acute stimulation.

The results presented herein are consistent with those obtained in furosemide-treated newborn lambs $(30,40)$ and in newborn lambs (4) and human neonates after blood volume depletion (9), showing that the RAAS is responsive to acute challenge in spite of its high baseline activity.

Furthermore, in the present study, we could demonstrate that following furosemide administration, urinary $\mathrm{PGE}$ and $\mathrm{PGF}_{2 \alpha}$ also increased. These results suggest the involvement of renal PG's in the mechanisms of water and sodium diuresis as well as stimulation of RAAS by furosemide in the neonatal period. In support of this possibility, the following findings should be taken into account: (1) furosemide has been shown to increase PRA, PA, and urinary $\mathrm{PGE}$ and $\mathrm{PGF}_{2 a}$ excretion along with the increase of sodium and water diuresis in healthy volunteers (1); (2) furosemide results in increased PG precursor, arachidonic acid release, and the effect of furosemide on renin release, and renal blood flow has been assumed to be the consequence of the increased arachidonic acid availability and the subsequent enhancement of PG synthesis (41); (3) indomethacin, a potent inhibitor of PG synthesis, prevents the rise in urinary sodium excretion, PRA, and PA induced by furosemide $(25,27,39,41) ;(4)$ in low-birth-weight sick premature infants, furosemide has been reported to increase urinary PGE excretion, and this increase could be prevented by indomethacin administration (11).

In view of the widespread use and apparent clinical acceptance of furosemide and indomethacin treatment in the management of sick neonates and the possible role of PG's in controlling renal sodium excretion and the activity of RAAS, it would be of great importance to define the normal values for plasma $P G$ levels and urinary PG excretion in the neonatal period. However, scanty and contradictory data are available on PG's during this early period of life. Siegler et al. (32) found plasma PGE levels to be significantly lower in normal term infants at age of 2 to 3 days than in children and adults. More recently Mitchell et al. (23), using extremely sensitive and specific radioimmunoassay, could demonstrate that plasma PGE, PGF, and 13,14-dihydro-15-oxo-prostaglandin $\mathrm{F}$ were much greater during the first month of life than were those found in normal adults. There was no difference in neonatal plasma PG levels at 6 days of age after term and preterm delivery. They also noted that following preterm delivery plasma PG concentrations gradually declined as the postnatal age advanced from 2 to 4 days to 5 to 8 wk.

Evidences are accumulating to indicate that the newborn infants have significantly lower urinary PG excretion when compared with those of healthy children and adults $(7,11,38)$. We found that urinary PGE excretion of healthy premature infants was very low during the first wk, and it was rapidly increasing until the third wk and remained practically unchanged during the next two wk of life (38). Brouhard et al. (7), however, failed to observe any significant difference in PGE and prostaglandin A excretion between the neonates of different gestational and postnatal ages in the ranges of 31 to $35 \mathrm{wk}$ and 1 to 28 days, respectively.

This apparent conflict of results may be attributed to the differences in either the criterion for selection of subjects or in the experimental designs and methods applied. Further studies are needed to provide more direct information about renal production and plasma levels of PG's in healthy and sick neonates for understanding their importance in neonatal homeostasis, particularly in the interaction of renal PG's and the function of RAAS.

\section{CONCLUSION}

On the basis of our observations, we conclude that RAAS of the neonate responds to acute furosemide challenge in spite of its high baseline activity, and its response may be mediated by increased renal PG production.

\section{REFERENCES AND NOTES}

1. Abe, K., Irokawa, N., Yasujima, M., Seino, M., Chiba, S., Sakurai, Y., Yoshinaga $K$.. and Saito. T.: The kallikrein-kinin system and prostaglandins in the kidney. Their relation to furosemide-induced diuresis and to the renin-angiotensinaldosterone system in man. Circ. Res., 43: 254 (1978).

2. Aranda, J. W., Perez, J., Sitar, D. S., Collinbe, J., Portuguez-Malavasi, A., Duffy, B., and Dupont, C.: Pharmacokinetic disposition and protein binding of furosemide in newborn infants. J. Pediatr., 93: 507 (1978).

3. Beitins, I. Z., Bayard, F.. Levitsky, L., Ances, I. G., Kowarski, A.., and Migeon, C. $J$. Plasma aldosterone concentration at delivery and during the newborn period. J. Clin. Invest., 51: 386 (1972).

4. Broughton Pipkin, F., Kirkpatrick, S. M. L., Lumbers, E. R., and Mott, J. C. Renin and angiotensin-like levels in foetal, new-born and adult sheep. $J$. Physiol., 241: 575 (1974).

5. Broughton Pipkin, F., and Smales, O. R. C.: Blood pressure and angiotensin II in the newborn. Arch. Dis. Child., 50: 330 (1975).

6. Broughton Pipkin, F., and Symonds, E. M.: Factors affecting angiotensin II concentrations in the human infants at birth. Clin. Sci. Mol. Med., 52: 449 (1977).

7. Brouhard, B. H., Aplin, C. E., Cunningham, R. J., and LaGrone, L.: Immunoreactive urinary prostaglandins $A$ and $E$ in neonates, children and adults. Prostaglandins, 15: 881 (1978).

8. Dillon. M. J., Gillon, M. E. A., Ryness, J. M., and deSwiet, M.: Plasma renin activity and aldosterone concentration in the human newborn. Arch. Dis. Child., 5I: 537 (1976).

9. Dillon, M. J., Rajani, K. B., Shah, V., Ryness, J. M., and Milner, D. G.: Renin and aldosterone response in human newborns to acute change in blood volume. Arch. Dis. Child., 53: 461 (1978).

10. Dunn, M. J., and Hood, V. L.: Prostaglandins and the kidney. Am. J. Physiol. 233: 169 (1977).

11. Friedman, Z., Demers, L. M., Marks, K. H., Uhrmann, S., and Maisels, M. J. Urinary excretion of prostaglandin $E$ following the administration of furosemide and indomethacin to sick low-birth-weight infants. J. Pediatr., 93: 512 (1978)

12. Frölich, J. C., Hollifield, J. W., Wilkinson, G. R., and Oates, J. A.: Effects of indomethacin on furosemide stimulated renin and sodium excretion. Circ Res.. 52 (Suppl. 2): 99 (1975).

13. Gill, J. R. Frölich, J. C., Bowden, R. E., Taylor, A. A., Keiser, H. R., Seyberth H. W., Oates, J. A., and Bartter, F. C.: Bartter's syndrome: a disorder characterized by high urinary prostaglandins and a dependence of hyperreninemia on prostaglandin synthesis. Am. J. Med., 61: 43 (1976).

14. Godard, C., Gaillard, R., and Vallotton, M. B.: The renin-angiotensin-aldosterone system in mother and fetus at term. Nephron, 17: 353 (1976).

15. Greenberg, A. J., McNamara, H., and McCrory, W. W.: Renal tubular response to aldosterone in normal infants and children with adrenal disorders. J. Clin. Endocrinol. Metab., 27: 1197 (1967)

16. Gutierrez-Cernosek, R. M., Morill, L. M., and Levine, L.: Prostaglandin F $F_{2}$ levels in peripheral sera of man. Prostaglandins, 1: 71 (1972).

17. Haber, E Koerner, T. Page, L. B., Kliman, B., and Purnode, A.: Application of a radioimmunoassay for angiotensin I to the physiologic measurements of
plasma renin activity. J. Clin. Endocrinol. Metab., 29: 1349 (1969).

18. Hayduk, K., Krause, D. K., Huengers, R., and Unbenhaun, V.: Plasma renin concentration at delivery and during the newborn period in humans. Experimentia. 28: 1489 (1972)

19. Jaffe, B. M. Behrman, H. R., and Parker, C. W.: Radioimmunoassay measurement of prostaglandin E, A and F in human plasma. J. Çlin. Invest., 52: 398 (1973).

20. Katz, P. H., Beck, P., and Makowski, E. L.: The renin-aldosterone system in mother and fetus at term. Am. J. Obstet. Gynecol., 118: 51 (1974).

21. Lammintausta, R., Eronen, M., and Erkkola, R.: The effect of normal labor on the renin-angiotensin system in mother and fetus. Am. J. Obstet. Gynecol., 127: 390 (1977). 
22. Lumbers. E. R., and Reid, G. C.: Effects of vaginal delivery and caesarean section of plasma renin activity and angiotensin II levels in human umbilical cord blood. Biol. Neonate, 31: 127 (1977).

23. Mitchell, M. D., Lucas, A., Etches, P. C., Brunt, J. D., and Turnbull, A. C Plasma prostaglandin levels during early neonatal life following term and preterm delivery. Prostaglandins, I6: 319 (1978).

24. Mott, J. C.: The place of the renin-angiotensin system before and after birth. $\mathrm{Br}$ Med. Bull., 31: 44 (1975).

25. Patak. R. V., Mookerjee, B. K., Bentzel. C. J., Hysert, P. E., Babeu, M., and Lee. J. B.: Antagonism of the effects of furosemide by indomethacin in normal and hypertensive man. Prostaglandins, 10: 649 (1975).

26. Raux-Eurin, M. C., Pham-Huu-Trung, M. T., Marrec, C., and Girard, F.: Plasma aldosterone concentrations during the neonatal period. Pediatr. Res., $11: 182$ (1977).

27. Romero, J. C.. Dunlap, C. L., and Strong, C. G.: The effects of indomethacin and other anti-inflammatory drugs on the renin-angiotensin system. J. Clin. Invest. 58: $282(1976)$.

28. Ross, B. S., Pollak, A., and Oh, W.: The pharmacologic effects of furosemide therapy in the low-birth-weight infant. J. Pediatr., 92: 149 (1978).

29. Saruta, T.. and Kaplan. N. M.: Adrenocortical steroidogenesis: the effects of prostaglandins. J. Clin. Invest.. 51: 2246 (1972)

30. Siegel, S. R., and Fisher, D. A.: The renin-angiotensin-aldosterone system in the newborn lamb: response to furosemide. Pediatr. Res.. 11: 837 (1977).

31. Siegel, S. R., Fisher, D. A., and Oh, W.: Serum aldosterone concentrations related to sodium balance in the newborn infants. Pediatrics, 53: 410 (1974).

32. Siegler, R. L., Walker, M. B., Crouch, R. H., Christenson, P., and Jubiz, W.: Plasma prostaglandin E concentrations from birth through childhood. $\mathrm{J}$. diatr.. 91: 734 (1977)

33. Solc, J., and Knorr. D.: Die Wirkung Aldosteron und Spirolacton auf die Ausscheidung von Natrium und Kalium im Harn bei neugeborenen und Sauglingen. Z. Kinderheilk., /16: 143 (1974).

Copyright ( $\odot 1980$ International Pediatric Research Foundation, Inc. $0031-3998 / 80 / 1405-0765 \$ 02.00 / 0$
34. Spitzer, A., and Brandis, M.: Functional and morphologic maturation of the superficial nephrons and relationship to total kidney function. J. Clin. Invest.. 53: 279 (1974).

35. Sulyok. E.. Németh, M., Tényi, I., Csaba, I. F., Györy. E., Ertl, T., and Varga F.: Postanatal development of renin-angiotensin-aldosterone system (RAAS) in relation to electrolyte balance in premature infants. Pediat. Res.. 13: 817 (1979).

36. Sulyok, E.. Németh. M., Tényi, I., Csaba, I. F., Thurzó, V., and Hadnagy, J.: The possible role of prostaglandins in the neonatal hyperfunction of renin-angiotensin-aldosterone system. Br. J. Obstet. Gynaecol., 86: 205 (1979).

37. Sulyok, E., Németh, M., Tényi, I., Csaba, I. F.. Varga, F., Györy, E., and Thurzó. $V$.: Relationship between maturity, electrolyte balance and the function of the renin-angiotensin-aldosterone system in newborn infants. Biol. Neonate, 35 . $60(1979)$.

3x. Sulyok, E., Ertl, T., Csaba. I. F., and Varga, F.: Postnatal changes in urinary

prostaglandin E excretion in premature infants. Biol. Neonate, 37: 192 (1980). furosemide

Trimper, C. E indomethacin. J. Clin. Endocrinol. Metab., 45: 147 (1977). rimper, C. E., and Lumbers, E. R.: The renin-angiotensin system in foetal
lambs. Pflugers Arch. Eur. J. Physiol. 336. $1(1972)$ 41. Weber. Pflugers Arch. Eur. J. Physiol.. 336: 1 (1972).

41. Weber, P. C.. Scherer, B., and Larsson, C.: Increase of free arachidonic acid by furosemide in man as a cause of prostaglandin and renin release. Pharmacol., 41: 329 (1977)

42. Wetter. W., Wetter, H., and Siegenthaler. W.: Radioimmunoassay for aldosterone without chromatography. 2. Determination of plasma aldosterone. Acta Endocrinol., 74: 558 (1973).

43. Requests for reprints should be addressed to: E. Sulyok, M.D.. Department of Obstetrics/Gynecology, the First Department of Medicine. University of Pess. Pécs, Hungary.

44. Received for publication January 16, 1979

45. Accepted for publication August 21, 1979 